\title{
W poszukiwaniu jednostki mowy. Metodologiczne refleksje w obliczu nowego rozumienia języka
}

\author{
Jolanta Antas \\ Uniwersytet Jagielloński w Krakowie \\ jolanta.antas@uj.edu.pl
}

\section{Malgorzata Majewska}

Uniwersytet Jagielloński w Krakowie gomajewska@gmail.com

\section{Streszczenie}

Celem tego artykułu jest rewizja takich pojęć jak zdanie, wypowiedź, akt mowy, zdarzenie komunikacyjne w obliczu nowych potrzeb badawczych i szerszego rozumienia języka - języka uwikłanego $w$ złożony proces komunikowania, a zatem jako narzędzia służacego nie tyle do produkcji znaczeń, ile do ich przekazywania i interpersonalnego wspóttworzenia. Z takiej perspektywy język jawi się nie jako system, ale jako jedno z narzędzi symbolizowania znaczeń $i$ intencjonalnych przestań, które służa do wytwarzania i regulowania więzi społecznych.

Zamiarem autorek jest zatem taka redefinicja tradycyjnych dla językoznawstwa i pragmatyki mowy pojęć, aby stały się one dobrym narzędziem dla opisu typu zdarzenia komunikacyjnego $i$ wytworzonej jednostkowej interakcji. Chcemy tez usunać istniejace zamieszanie terminologiczne, tzn. wyeliminować używanie tych samych pojęć dla określenia innych zjawisk mownych lub innych poziomów mowy, a w rezultacie zhierarchizować te pojęcia oraz wytyczyć im przejrzyste ramy definicyjne. A wszystko to po to, by $w$ tych ramach dała sie zawrzeć także perspektywa odbiorcy jako czynnego uczestnika $i$ wspóltwórcy komunikacyjnego zdarzenia, wypowiedzi, a nawet zdania.

Słowa kluczowe: wypowiedź, zdanie, jednostka mowy, zdarzenie komunikacyjne, zdarzenie mowne, akt mowy

\begin{abstract}
In Search of a Unit of Speech. Methodological Reflections Sparked by a New Understanding of Language

The article aims at a revision of such terms as sentence, utterance, speech act, or communication event in view of new research needs and a broader understanding of language as involved in a complex communication process and thus considered a tool of not
\end{abstract}


only generating meanings, but also conveying them in interpersonal collaboration. From such a perspective language appears to be not only a system, but also one of the tools of symbolizing meanings and intentional acts which serve the purpose of generating and regulating social bonds. The purpose of the authors is thus to define traditional linguistic concepts in order to makes them good tools to describe the types of communication events and the ensuing individual interactions. We also intend to resolve the existing terminological confusion, i.e. to eliminate the employment of the same terms to describe different speech events and different levels of speech, and as a result to place the concepts in a hierarchy and assign them clear definitions. All this is undertaken in order to fit in the perspective of the observer as an active participant and contributor to the communication event, utterance or even a sentence.

Keywords: utterance, sentence, unit of speech, communication event, speech event, speech act

\section{Wstęp}

Zacznijmy od rewizji rozumienia najbardziej podstawowej jednostki języka z poziomu konstrukcji wypowiedzi, jaką jest zdanie. Zdanie - przez wszystkich uznawane za niezbywalną jednostkę języka, wywołuje bodaj najwięcej polemik i sporów definicyjnych. $\mathrm{Na}$ gruncie językoznawstwa tradycyjnego doczekało się ponad dwustu definicji, wśród których wyróżnić można trzy grupy: definicje strukturalne, strukturalno-semantyczne i semantyczne.

1.1. Grupę pierwszą stanowią definicje strukturalne. Należą do niej definicje, które:

a). „określają zdanie jako wyrażenie nie mające żadnych relacji zewnętrznych gramatycznych, czyli jako jednostkę strukturalnie autonomiczną" (Polański 1999: 669). Mankamentem tej definicji jest - zdaniem badaczy języka to, że poza jej obrębem pozostałyby wszystkie ,zdanio-wypowiedzi", które w swej strukturze gramatycznej takie wskaźniki posiadają. A patrząc na rzecz z perspektywy samej mowy, zdania właśnie posiadające takie wskaźniki zewnętrznego nawiązania są bardziej naturalne, bo zdanie na ogół jest komunikacyjną reakcją na coś. Jak choćby obecność spójnika przeciwstawnego ale w zdaniu: Ale w końcu przegrat. czy obecność odnośnika czasowego typu wtedy w zdaniu: I wtedy ogarnęly mnie watpliwości.

b). Innym zabiegiem strukturalnym jest wyznaczenie jednostki zdania przez określenie jego właściwości kompozycyjnych. „Według jednych zdanie jest konstrukcją syntaktyczną, dychotomicznie złożoną z podmiotu i orzeczenia, według innych - konstrukcją, której 
wyróżnikiem jest obecność osobowej formy czasownika". (Polański 1999: 669-670). Ale i te definicje mają swoje poważne ograniczenia, co podkreślali sami ich zwolennicy. To powszechnie znane argumenty, ale przypomnijmy je pokrótce. A mianowicie: definicje te nie obejmują, jeśli je rozumieć dosłownie, zarówno zdań jednoczłonowych (zwłaszcza zdań bezpodmiotowych np. Powiało chłodem. czy Dnieje., jak i zdań, w których brak jest formy osobowej czasownika i których tą formą uzupełnić nie można, np.: Strach pomyśleć. czy Widać tak trzeba.

1.2. Grupę drugą stanowią definicje mieszane: strukturalno-semantyczne $\mathrm{z}$ różnym rozkładem akcentów na cechach strukturalnych i semantycznych. Do nich należy między innymi szeroko znana w składni polskiej definicja Zenona Klemensiewicza, według której zdanie to „twór językowy, stanowiący w określonych warunkach komunikatywną całość i zawierający osobową formę orzeczenia". (Polański 1999: 669-670) W wielu innych tego typu definicjach powtarzają się sformułowania mówiące o tym, że zdanie jest jednostką językową o określonej budowie, reprezentującą pewną skończoną myśl lub mającą pełny sens (Polański 1999: 670). Szkoda jednak, że nie precyzowano, jak rozumieć ową skończoną myśl czy pełny sens i jak interpretować stwierdzenie dotyczące owych określonych warunków, w jakich dana konstrukcja stanowi komunikatywną całość. Mało tego, trudno jest często pogodzić wymogi formalne z postulatem „całości” semantycznej, jako że z jednej strony takimi „całostkami” semantycznymi bywają wypowiedzi pozbawione osobowej formy czasownika, jak np.: Warto czasem pomyśleć. czy Czuć tu gaz., z drugiej zaś nie każda forma predykatywna (wyrażona osobową formą czasownika) stanowi formalnie skończoną myśl, np.: *Paweł jest mniejszy (bez wyrażenia porównania), choć może być jak najbardziej pełną wypowiedzią.

1.3. Z kolei zgodnie z definicjami semantycznymi, „to nie struktura formalna wyznacza zdanie, ale sens". (Polański 1999: 670) Za cechę relewantną jednostki zdaniowej uznaje się jej komunikatywną zupełność, a tym samym semantyczną niezależność od kontekstu językowego i sytuacyjnego. Owa komunikatywna zupełność zasadza się na założeniu, że zdanie jest wyrażeniem, które stwierdza coś o wskazanym fragmencie rzeczywistości. Musi zatem obligatoryjnie posiadać strukturę tematyczno-rematyczną, czyli element wskazujący na to, o czym orzeka (temat) i element wskazujący o tym, co orzeka (remat). Owa zupełność komunikatywna rozumiana jest następująco: zdanie jest taką wypowiedzią, która w sposób skończony i w pełni orzeka o zaistnieniu czegoś. Mankamentem tego typu definicji jest naszym zdaniem - paradoksalnie warunek ich semantycznej zupełności. Tzn. wszystkie elementy sensu, takie jak: czas, miejsce, modalność zdarzenia (zob. omówienie „ramy 
modalnej" poniżej) itd. muszą być wyrażone. To zaś powoduje, że tylko niewielka liczba naszych orzekań o rzeczywistości fizycznej i psychicznej mogłaby być uznana za zdanie w zgodzie z tymi wymogami. I tak wypowiedź: Dzisiaj wołowina jest na pewno nieobecna w mojej lodówce. jest semantycznie zupełna, a zatem w myśl definicji semantycznej spełnia wszystkie warunki bycia zdaniem, poza być może jednym - komunikacyjnym i pragmatycznym, bo mało kto tak powie. Z kolei poszczególne naturalno-językowe sekwencje wypowiedzi w postaci np.: Nie ma wołowiny. Zagladałem do lodówki. Na pewno nie ma. Sprawdzałem przed chwila. jednostkowo nie nadają się na zdania, przynajmniej zupełne semantycznie. Paradoksalnie jednak nikt nie mówi zupełnymi zdaniami, a ich skończona sensowność nie jest ad hoc zawarta w umyśle jednego użytkownika. Ona tworzy się, powstaje w interakcji. Sens semantyczny bowiem nie tkwi w umyśle danej jednostki i nie rodzi się w komunikacyjnej próżni, ale przejawia się i tworzy w toku wymiany myśli w obliczu komunikacyjnego zdarzenia.

1.4. Chyba najbardziej elastyczną definicję zdania i najbardziej obiecującą dla badania zjawisk mowy zaproponowała kognitywna orientacja lingwistyczna. Obiecującą, bo uwzględniającą aż trzy aspekty: składniowy, semantyczny i pragmatyczny. Kognitywiści zakładają bowiem, że konstrukcja zdaniowa składa się z kilku warstw lub poziomów, których elementy składowe wchodzą ze sobą w wzajemne związki. Zakładają zatem (por. Tabakowska 2001: 111-143), że zdanie:

a. wyraża określony schemat zdarzeniowy,

b. ma określoną strukturę składniową

c. jest osadzone w określonym kontekście pragmatycznym.

Wyjaśnijmy to:

Co to znaczy, że zdanie wyraża określony „schemat zdarzeniowy”? Oznacza to, że określone zdanie jest „gramatycznym” wyrazicielem pewnej ontycznej i semantycznej sceny zdarzeń, w której uczestnikom przypisano określone role, a zdarzeniom - stany lub akcje. Stąd „schematy zdarzeń” są nosicielami pewnych ontycznych orzekań, wyrażonych w określonych semantycznych porządkach, takich jak: BYCIE, DZIAŁANIE, POSIADANIE, DOZNAWANIE, PRZEMIESZCZANIE itp. Zaś schematy zdań tworzą szkielety konstrukcyjne dla wyrażenia podstawowych schematów zdarzeniowych. Dlatego kognitywiści chętniej mówią o schemacie zdaniowym niż o zdaniu.

Co zatem oznacza, że zdanie ma określoną strukturę składniową? Schemat danej struktury składniowej jest na ogół wyrazicielem jednego schematu zdarzeń ${ }^{1}$, zaś jednostkowe 
zdanie, posiadające określoną strukturę składniową, jest wyrazicielem konkretnej budowy i organizacji sceny zdarzeń, dającej się podciągnąć pod dany schemat.

Co w końcu oznacza, że zdanie nie istnieje poza określonym kontekstem pragmatycznym? Najprościej oznacza to, że zdanie nigdy nie istnieje i nie zaistnieje w jakiejś komunikacyjnej próżni ${ }^{2}$. Bühler powiedziałby zapewne, że powstaje ono tylko wtedy, gdy wypowiada je konkretny nadawca, w konkretnym czasie i konkretnym miejscu, a pragmatyka dorzuca, gdy mówi to w konkretnym celu. Wszystkie te składowe mają swoje formalne wykładniki w strukturze zdania i uzasadniają jego ontologiczne zaistnienie - kognitywiści określają je mianem elementów kotwiczących. Kotwiczenie uzasadnia zatem i odpowiada za konieczność zanurzenia zdania w rzeczywistości pozajęzykowej, i to nie tylko w rzeczywistości czasowo-przestrzennej, ale i epistemicznej: sądu, przypuszczenia, pytania, twierdzenia itd.

Spróbujmy przez chwilę przyjrzeć się samym mechanizmom kotwiczenia i zobaczyć, czy istnieje jakaś ich hierarchizacja, i jak wyznacza ona jądro zdaniowe.

Według kognitywistów jądrem „zdaniotwórczym” jest samo wydarzenie. Oczywiście ono samo, ani nawet jego percypowanie przez podmiot, nie może jeszcze stanowić ,jądra” zdaniowego. Może jednak i stanowi ,jądro" procesu postrzegania czegoś jako zdarzenie. A taki stan umysłu wyraża jego gotowość do predykacji (orzekania). I ten stan i wola jego zwerbalizowania dopiero stanowią jądro zdaniotwórcze. Widzimy zatem, że u podstaw kognitywnego rozumienia zdania tkwi pewna mentalna gotowość umysłu (jego „predyspozycja kategorialna”) do orzekania o zdarzeniach (czyli epistemicznej obróbki ontologicznych zjawisk). Zdanie zatem - można by tak powiedzieć - jest raczej pewną predyspozycją semantyczną niż składniową (predyspozycją do kategoryzacji procesów, stanów, wreszcie ich przemieszczania, przekazywania, posiadania i doznawania). Ta predyspozycja semantyczno-mentalna nie może odbywać się bez udziału żywej, obecnej i aktualnie postrzegającej percepcji. Dlatego nie może dziwić fakt, że według kognitywistów jądrem zdaniowym jest forma niedokonana orzeczenia, ponieważ takie orzekanie nie przesądza jeszcze o faktycznym zajściu zdarzenia. Kiedy podmiot mówi: Marysia szyje sukienkę., nie zna rezultatów tej czynności. Dlatego zdarzenie samo w sobie nie jest jeszcze zakotwiczone. Marysia mogła nie uszyć sukienki. Pierwsze zakotwiczenie dokonuje się w warstwie zdaniowej przez orzekanie o dokonaniu się czynności. Podmiot orzeka wtedy, że czynność zaszła, są jej skutki i rezultaty. Powie wtedy: Marysia uszyła sukienkę. A zatem ta sukienka jest. 
Drugie zakotwiczenie deiktyczno-czasowe według kognitywistów to sposób wyrażenia relacji między zdarzeniem, zachodzącym w czasie rzeczywistości pozajęzykowej, a czasem komunikatu językowego, co wyraża się czasem gramatycznym. Oznacza to, że wybór danej gramatycznej kategorii czasowej determinowany jest każdorazowo s u b i e k t y w n i e pojmowaną osią czasową mówiącego podmiotu (tj. momentem, w którym on właśnie mówi). Wynika więc $\mathrm{z}$ tego, że obligatoryjne dla zdania gramatyczne wyrażanie czasu determinowane jest usytuowaniem siebie (tj. mówiącego podmiotu) w czasie „teraz” i odniesieniu owego „teraz” do czasu zdarzenia, o którym ten podmiot orzeka. Innymi słowy, deiktyczność odniesień czasowych wyznacza porządek gramatyczny zdania. Oznacza to też, że podmiot dokonując wyboru czasu gramatycznego dla orzekania o zdarzeniu, ustanawia swoją bliskość lub czasową odległość wobec opisywanego zdarzenia (zajścia, faktu).

Trzecie zakotwiczenie wyraża stosunek mówiącego do prawdziwości wypowiadanego przez niego komunikatu, czyli tworzy tzw. ramę modalną. Mówiący jest albo przekonany, że zdarzenie, które opisuje jest faktem, albo też traktuje je jako hipotetyczne. Sąd nienacechowany nie posiada specjalnych wykładników, ale już najmniejsze wahanie co do jego prawdziwości musi być wyrażone leksykalnie lub - dorzućmy - parajęzykowo. Kognitywiści nie mówią jednak, czy wszystkie rodzaje modalności miałyby stanowić jądro kotwiczące zdania. Sądzimy, że rozsądnie byłoby zawęzić jego obszar semantyczny jedynie do modalności aletycznej, czyli decyzji o hipotetyczności zdarzenia, czy też faktycznym jego zaistnieniu lub wreszcie faktycznym niezaistnieniu. Dlaczego tak? Ponieważ modalności typu epistemicznego i deontycznego należą już do sfery poznawczej i postulowanej przez podmiot, a nie do sfery ontycznie orzekanej.

Ostatnia, czwarta i najbardziej zewnętrzna warstwa kotwicząca zdanie według kognitywistów wyraża jego funkcje pragmatyczne: to, czy postulowany stan jest oznajmieniem, pytaniem czy też jest życzony sobie, co gramatycznie wyrażane jest trybami (trybem oznajmującym, pytającym, rozkazującym). I znów małe zastrzeżenie. Kognitywiści ten poziom czy warstwę zdaniotwórczą utożsamiają z aktem mowy, gdy tymczasem akt mowy to pojęcie szersze i nie da się go sprowadzić do gramatycznie wyrażonych trybów. Deklaratywa i ekspresywa, a także część aktów komisywnych niezwiązana jest z określonymi trybami gramatycznym. Innymi słowy, tryby są zgramatykalizowanym sposobem wyrażenia pewnych funkcji pragmatycznych, są nośnikami pewnych intencji i można kategorialnie im te intencje przypisać, ale ani nie wyczerpują kategorii intencji ludzkich wypowiedzeń, ani też nie zawsze użycie danego trybu gwarantuje przypisywaną mu gramatycznie intencjonalność. I tak, użycie trybu warunkowego w wypowiedzi typu: Czy mógłbyś mi wyttumaczyć, 
dlaczego zawsze zostawiasz skarpetki pod łóżkiem? nie jest sądem hipotetycznym, ani nawet pytaniem, tylko pretensją i wymówką; a pytanie typu Ile można gadać przez telefon? znów jest nie tyle pytaniem o „ontologię rozmowy telefonicznej", co złośliwym wytknięciem. Po drugie: języki na ogół wypracowały sobie gramatyczność niektórych funkcji pragmatycznych - ale nie wszystkich. Dobór tych funkcji wyznaczony jest przez antropologię języka oraz ich pragmatyczną użyteczność. ${ }^{3}$ I wreszcie po trzecie - co stało się oczywiste już dawno - ten sam tryb gramatyczny wykorzystywany jest do realizacji różnych funkcji pragmatycznych (jak np.: tryb przypuszczający służy konwencjom grzecznościowym).

Z tych wszystkich powyższych powodów, a także dlatego, że lingwistyka europejska wypracowała dość użyteczne pojęcia, takie jak wypowiedź i akt mowy, nie uważamy za konieczne utożsamiać ich ze zdaniem. Odwrotnie, wydaje się ze wszech miar słusznym metodologicznie uznać zdanie za jednostkę mniejszą od wypowiedzi mniej pojemną niż akt mowy. Mniejszą nie znaczy jednak fonologicznie mniej rozciągłą niż wypowiedź, a mniej pojemną - nie znaczy nieintencjonalną. Znaczy to tylko, że zdanie jest najmniejszą jednostką wypowiedzi, albo takim jej semantycznym przejawem, w którym podmiot dokonał pewnej konstatacji ,zaistnienia" jakiegoś stanu rzeczy, co nabrało gramatycznego wyrazu w formie orzekającej. Oznacza to jednak i to, że takie „orzekanie" nie musi mieć koniecznie formy gramatycznego orzeczenia (choć takie byłoby najbardziej prototypowe).

Konkludując, przyjmujemy, że prototypowe zdanie to czasownik w trybie niedokonanym, ale semantycznie to tryb aletycznego orzekania o zaistnieniu jakiegoś procesu, a potem stanu. Dlatego może być wyrażony innymi środkami gramatycznymi, takimi jak bezokolicznik, np.: Czuć tu spalenizną.; czy przez konstrukcje przysłówkowe (z elipsą osobowej formy czasownika) typu: Ponuro tu jakoś; Nudne te zajęcia, czy nawet konstrukcjami nominalnymi typu Spokój!, albo i pytajna-grzecznościowymi typu: Ciasteczka? lub też dyrektywnymi typu: Mała czarna! I wreszcie ostensywnie: gestem wskazującym i towarzyszącą mu konstrukcją zaimkową, taką jak odpowiedź na pytanie: Gdzie usiądziesz? Tutaj i wskazanie na pierwszy rząd krzeseł w sali wykładowej.

Takie rozumienie zdania jest $\mathrm{z}$ jednej strony zgodne $\mathrm{z}$ duchem kognitywnym, $\mathrm{z}$ drugiej jednak od niego odbiega. Zgodne, bo za jego podstawę uznajemy mentalną gotowość do orzekania o zachodzeniu jakiegoś procesu, co najczęściej gramatycznie (ale nie zawsze) wyraża się grupą werbalną o określonym schemacie składniowym; niezgodne - ponieważ warstwy kotwiczące modalność i funkcje pragmatyczne mowy dają się znakomicie przypisać wyższym niż zdanie jednostkom mowy, takim jak wypowiedź i akt mowy, a w końcu komunikacyjne zdarzenie. Modalność bowiem i inne funkcje pragmatyczne mogą 
realizować się W mowie bez uciekania się do konieczności uprzedniego aletycznego orzekania.

Wyjaśnimy to za chwilę, tymczasem prześledźmy lingwistyczną karierę słowa wypowiedź.

1. Termin wypowiedź do lingwistyki polskiej został wprowadzony przez Zenona Klemensiewicza na „oznaczenie zamkniętej i ukształtowanej składniowo jednostki komunikatywnej." (Polański 1999: 645) Zgodnie z tą koncepcją, wypowiedzenia ${ }^{4}$ dzielą się na zdania i oznajmienia. Nie wiemy jednak, czy oznajmienia są wynikiem komunikacyjnej interakcji i dlatego nie muszą być zdaniami, czy też mówiący ma komunikacyjną swobodę wyboru jednej czy drugiej formy jeszcze na poziomie systemu. Mylone są zatem dwa porządki: porządek jednostek systemu języka i porządek właściwości jednostek komunikacyjnych, co metodologicznie jest niepłodne. W nowszej lingwistyce terminu wypowiedź i jego angielskiego odpowiednika utterance używa się na oznaczenie konkretnego zdania wypowiedzianego przez konkretnego użytkownika języka. W takim rozumieniu wypowiedź przeciwstawiona jest zdaniu, które rozumie się jako bardziej abstrakcyjną jednostkę i zalicza do języka (langue) albo do kompetencji językowej (w terminologii gramatyki generatywnej).

2. W literaturze anglosaskiej i językoznawstwie francuskim problem różnicy między zdaniem i wypowiedzią był znaczący i ważny. Przykładowo Lyons pisał:

zaczniemy od odróżnienia zachowania językowego od systemu językowego, leżącego u jego podstaw. Kiedy powiadamy, że ktoś mówi określonym językiem, np. po angielsku, to chcemy przez to wyrazić, że ten ktoś przejawia pewne zachowania czy działalność, w której toku wytwarza sygnały głosowe o określonej długości oraz różne - podkreślmy to - sygnały n i e g ło s o w e, współdziałające z głosowymi, a niekiedy nawet rozstrzygające o ich interpretacji. Sygnały głosowe będziemy nazywać wypowiedziami. Termin wypowiedź (utterance) jest jednak niejednoznaczny w przeciwieństwie do francuskich terminów énonciation i énoncé: może on oznaczać zarówno pewien element zachowania (akt wypowiadania się - francuskie énonciation), jak i wytwór tego zachowania (francuskie énoncé). Te dwa znaczenia można w razie potrzeby zróżnicować za pomocą terminów wypowiedź-akt i wypowiedź-sygnat. Filozofowie zwykli chyba używać terminu wypowiedź w znaczeniu aktu czy działania, a językoznawcy - raczej w znaczeniu sygnału, choć według wyraźnych definicji Bloomfielda (1926) i Harrisa (1951) termin ten można rozumieć jako oznaczający jedno i drugie (Lyons 1989 $: 30)$. 
Według Harrisa (1951) - ,wypowiedzią jest wszelkie odezwanie się jednej osoby, przed którym i po którym ta osoba milczy”. (Lyons 1989: 31) „Wynika z tej definicji - według interpretacji Lyonsa - że wypowiedź może być dowolnie długa: może składać się z jednego wyrazu, z grupy wyrazów lub ze zdania [...], może obejmować cały ciąg zdań; może stanowić gramatycznie niekompletny fragment zdania lub większą liczbę takich fragmentów; może również być zdaniem (lub fragmentem zdania) zawartym w innym zdaniu. Krótko mówiąc, między wypowiedziami a zdaniami nie zachodzi żadna prosta odpowiedniość. Zarówno zachowanie mówiącego, jak i wytwarzane przez niego wypowiedzi są dostępne dla obserwacji i można je w pewnym stopniu opisać za pomocą terminów czysto fizycznych (czyli zewnętrznych). Innymi słowy terminy zachowanie językowe i wypowiedź [...] należą do przedteoretycznego, obserwacyjnego słownictwa lingwisty”. (Lyons 1989: 30)

Zauważmy, że w pewnym sensie Lyons, a właściwie Bloomfield i Harris, bo na ich stanowiskach opiera on swoje poglądy, jest prekursorski, a w pewnym zaś epigoński. Prekursorski, gdy zauważa, że zachowaniu językowemu mogą towarzyszyć sygnały niegłosowe, niekiedy nawet rozstrzygające o interpretacji znaczenia samej wypowiedzi. (31) Oznacza to bowiem, że Lyons zdawał sobie sprawę z roli, jaką w procesie komunikacji odgrywają środki niewerbalne i parajęzykowe. Dziś nawet słychać głosy, że model pragmalingwistyki, budowany $\mathrm{w}$ oparciu o akty mowy, bez uwzględniania zachowań niewerbalnych jest metodologiczną pomyłką. Prekursorski był też Lyons, a właściwie Harris, gdy sądził, że wypowiedzią jest wszelkie odezwanie się jednej osoby, przed którym i po którym ta osoba milczy, zaś Lyons, gdy pisał: „wypowiedzi są jednorazowymi zdarzeniami fizycznymi i jako takie mogą być opisywane w obserwacyjnym metajęzyku lingwistyki". (Lyons 1989: 31) Epigoński zaś gdy sądził, że: „Na ogół jednak językoznawców nie interesują wypowiedzi jako niepowtarzalne obiekty obserwacji. Interesują ich typy, a nie okazy; (...)” I dalej, gdy pisał: „Kiedy mówimy, że dwie wypowiedzi są okazami jednego typu, mamy na myśli to, że zachodzi między nimi pewnego rodzaju tożsamość strukturalna lub funkcjonalna, dzięki której użytkownicy języka ojczystego uznają je za identyczne. (...) dzisiejsi językoznawcy są zgodni co do tego, że dwie wypowiedzi-okazy mogą być jaskrawo różne akustycznie, a jednak w przekonaniu użytkownika języka ojczystego uchodzić za tożsame". (Lyons 1989: 31) I znów prekursorski, kiedy powątpiewał w realną możliwość takiej funkcjonalnej identyczności dwu wypowiedzi. Sam bowiem pisał:

„Nie jest też chyba możliwe, przynajmniej w znacznej większości wypadków, rozpoznawanie wypowiedzi jako okazów jednego typu na podstawie ich tożsamości funkcjonalnej jako reakcji na ten sam bodziec (co wymaga uprzedniego i niezależnego 
zgrupowania bodźców jako okazów określonego typu).” (Lyons 1989: 31) Dzisiejsi językoznawcy, a przynajmniej pragmatycy mowy, komunikatywiści i badacze zachowań niewerbalnych, dokładnie odwrotnie niż pisał to Lyons, są zgodni co do tego, że dwie wypowiedzi, jeśli się czymkolwiek różnią, są przejawami innych komunikacyjnych potrzeb i różnych intencjonalnych przesłań. Co więcej, dzisiejsze podejście do zjawisk mowy i języka idzie w kierunku właśnie obserwowania raczej zachowań językowych ludzi niż badania języka; raczej poszukiwania jednostki mowy niż jednostki języka. I tak radykalny zwolennik koncepcji komunikatywizmu i scjentystycznego podejścia do badań zjawisk językowych, Yngve, w swoich tezach z roku 1992 postulował między innymi:

„Zamiast badania języka - zajęcie się werbalnym i niewerbalnym komunikowaniem się ludzi. Zamiast opracowywania gramatycznych teorii języka - pracę nad naukowymi teoriami ujmującymi ludzi z komunikacyjnego punktu widzenia. [...] Zamiast poszukiwania „gramatycznych" własności języka badanie „właściwości komunikacyjnych" ludzi. Zamiast postrzegania ludzi jako używających języka oraz wypowiadających słowa i zdania zwrócenie uwagi na osiąganie przez nich założonych celów komunikacji. Zamiast postrzegania mówiącego jako użytkownika języka traktowanie go jak porozumiewający się podmiot (bowiem to pojęcie nie wiąże się z tradycją gramatyczną). (...) Zamiast wątpliwych definicji języka - zwrócenie się ku obserwowalnym zachowaniom traktowanym jak komunikacyjne - o ile wpływają one na kolejne, obserwowalne zachowania komunikacyjne bądź niekomunikacyjne tej · samej lub innej osoby.(...) Zamiast mówienia o znaczeniu jak o czymś przekazywanym za pomocą języka - badanie językowych i niejęzykowych zmian zachodzących w ludziach pod wpływem zachowań komunikacyjnych porozumiewających się z nimi podmiotów”. I wreszcie: „Zamiast mówienia, że wypowiedzi są pod pewnymi względami podobne, a pod innymi różne oraz że żadne dwie wypowiedzi nie są brzmieniowo takie same - zwrócenie uwagi na obserwowalne podobieństwa i różnice między aktywnością komunikacyjną ludzi nie ma bowiem wśród nich podmiotów odpowiadających sobie dokładnie pod względem komunikacyjnym.” (Yngve 1992: 515- 516 za: Korżyk 1999: 1617). Znamienne, że również na terenie badań nad komunikacją niewerbalną można mówić o podobnych tendencjach, czyli odejściu od badań typu typologicznego (klasyfikacji znaków niewerbalnych) na rzecz obserwacji konkretnych zachowań niewerbalnych w konkretnej interakcji i całości zdarzenia komunikacyjnego. Mark Knapp i Judith Hall tak opisali kierunki ewolucji badań nad komunikacją niewerbalną: „od analizy sytuacji nieinteraktywnych do badań nad interakcją, od studiów zachowań danej osoby do analizy zachowań obu uczestników procesu, (...) od perspektywy zakładającej jedno znaczenie i jeden cel do 
uznania, że w niektórych przypadkach można wyodrębnić kilka znaczeń oraz że dany sygnał może służyć kilku celom, od metod pomiaru, koncentrujących się niemal wyłącznie na mierzeniu częstotliwości i długotrwałości sygnałów do metod uwzględniających także warunki i sposób wystąpienia danego zachowania, wreszcie od prób kontrolowania kontekstu poprzez eliminację istotnych i wpływowych elementów do prób uwzględniania tych elementów, (...) a w końcu: od wyjaśniania zachowań niewerbalnych wyłącznie warunkami kulturowymi lub wyłącznie cechami biologicznymi do prób jednoczesnego uwzględnienia obu obszarów". (Knapp, Hall 2000: 48)

Zreasumujmy:

Chciałoby się zachować jakąś jednostkę systemu, i żal pomyśleć, że jej nie ma, ale tak naprawdę, w realnej rzeczywistości językowej nawet taka jednostka jak zdanie nie istnieje bez kotwiczenia. Łatwiej zatem zdefiniować jednostki mowy niż mówić o jednostkach systemu. Niech wypowiedź pozostanie fizyczną realnością mowną, a zdanie jednym z jej przejawów - aletycznego orzekania. To bowiem natychmiast uzasadnia, dlaczego bywa tąk, że w zdarzeniu mownym, raz ,zdaniujemy”, a innym razem nie. Kiedy przykładowo optuję za inną realnością niż mówi rozmówca, to na dyrektywę zdaniową typu: Usiądź proszę, wyznaczę nową optykę zdarzeń i powiem przykładowo: Nie, postoję. Gdy jednak przyjmę tę optykę, mogę powiedzieć tylko Dziękuję. i usiąść. Podobnie gdy zapytam: Stuchasz mnie?, mój odbiorca może mruknąc tylko Mhm., czy No, a nawet tylko kiwnąć głową, ale gdy on sam optuje za inną sceną zdarzeń, orzeknie coś w czymś w rodzaju: Nie widzisz, że zmywam?. To tłumaczy i taką oczywistą różnicę między zdaniem a wypowiedzią, którą podkreślali badacze mowy, a mianowicie, to ,że w potocznej rozmowie wypowiedzi są najczęściej tak czy inaczej niekompletne gramatycznie lub eliptyczne.” (Lyons 1989: 32) Tak naprawdę ich niekompletność gramatyczna (jeśli ktoś już chce zachować to wyrażenie) jest ściśle uzasadniona komunikacyjną kompetencją. Do mownej; a zatem także komunikacyjnej kompetencji należy zapewne także właściwy dobór środków językowych dla wyrażenia określonej intencji i osiągnięcia zamierzonych pragmatycznych celów. Czyli dokonanie właściwego aktu mowy. Przyjrzyjmy się zatem na krótko lingwistycznej historii tego pojęcia i zastanówmy, czy istnieje jakaś różnica między wypowiedzią a aktem mowy.

Ferdynand de Saussure mówił o składowych indywidualnego aktu mowy, doceniając rolę nadawcy i odbiorcy, ale przez akt mowy rozumiał właściwie każdą językowo-foniczną transmisję obrazu akustycznego z ust i mózgu mówiącego do uszu i mózgu słuchającego. Ale transmisja „sensów" to jeszcze nie pragmatyczna intencjonalność i komunikacyjny cel przesłania danego obrazu akustycznego. 
Karl Bühler stawiał akt mowy na nieco wyższym stopniu abstrakcji. Uznawał go wprawdzie za konkretny przejaw jednorazowego mówienia jednostkowego, ale przypisywał mu wyższy stopień formalizacji, a co za tym idzie, przejaw raczej świadomości językowej niż działania językowego. (por. Polański 1999: 27) Innymi słowy, Bühler sądził, że działanie językowe ma charakter subiektywny i słabo sformalizowany. Jest zatem raczej ekspresją myśli i emocji niż ich świadomym wyrazem. Dopiero „akt językowy” w jego ujęciu jest działaniem komunikacyjnie świadomym - mówiący dokonuje wyboru formy lub formuły językowej, która - jego zdaniem - wyraża określane potrzeby wypowiedzenia się.

Można by więc sądzić, że Bühlerowskie rozróżnienie między działaniem językowym a aktem mowy to rozróżnienie dotyczące poziomu świadomości i kompetencji językowych. Ale chyba nie tylko. Bühler myśląc o stopniach formalizacji i subiektywizacji tworów językowych wykazywał świadomość uczestnictwa w procesie komunikacji zarówno nadawcy, jak i odbiorcy. A zatem jednoczesna dbałość o właściwą reprezentację treści umysłowych nadawcy, jak i właściwy dobór środków symbolicznych, i wreszcie świadomość tego, jakie one mogą wywoływać reakcje u odbiorcy daje podstawę do tego, by określone działanie językowe uznać za akt mowy. Gdybyśmy to chcieli ująć prościej, można by powiedzieć, że każda ekspresja mowna jest działaniem językowym, ale niekoniecznie aktem mowy. Przykładowo, gdy wyrażamy oburzenie uporczywym i natrętnym wykrzyknikiem (najbardziej popularnym w Polsce wulgaryzmem na k...) niekoniecznie wykazujemy jeszcze dbałość o odbiorcę, a chyba mniej jeszcze o właściwą reprezentację naszych treści to oburzenie wywołujących. Dopiero próba zobiektywizowania i usymbolicznienia językowego byłaby jak sądzimy - zdaniem Bühlera - dokonaniem aktu mowy, czyli świadomym opisem mentalnych i emocjonalnych doznań dla określonych, symbolicznych treści. Widać, że Bühler mocno czuł różnicę między przejawem mowy, a świadomym działaniem językowym. I dopiero to drugie uznałby za akt mowy. Z punktu widzenia jednak samej pragmatyki mowy trudno wyznaczyć ostre granice między świadomym i nieświadomym działaniem mownym, a tym bardziej wyznaczyć czyste granice jego formalizacji.

Ta sama formuła czy nawet czysta ekspresja może być fortunna lub nie, świadoma intencjonalnie lub nie w innym zdarzeniu komunikacyjnym. Trudno też orzec o stopniu jej sformalizowania. Konwencja bowiem bywa często sformalizowana, ale niekoniecznie bardziej złożona abstrakcyjnie. Może zatem lepszym sposobem ujęcia dychotomii Bühlera byłoby mówienie nie o świadomości językowej, ale o świadomości językowego użycia, czyli poziomu komunikacyjnego. Wtedy każde działanie językowe, każda wypowiedź byłaby 
aktem mowy, ale niekoniecznie fortunnym, właściwym retorycznie i kompetentnym komunikacyjnie.

Znak równości między aktem mowy i wypowiedzią stawiali też amerykańscy deskryptywiści, ale interpretowali go w behawiorystycznych kategoriach bodźca i reakcji. W ujęciu Leonarda Bloomfielda „wypowiedzenie jest reakcją na jakiś bodziec, który może mieć charakter bądź pozajęzykowy, bądź językowy. Sama wypowiedź mówiącego jest bodźcem językowym dla słuchającego, który może na nią zareagować albo jakąś czynnością (np. spełniając prośbę lub rozkaz mówiącego), albo własną wypowiedzią, czyli językowo". (Polański 1999: 28) Takie ujęcie poszerza rozumienie aktu mowy zarówno o reakcję niewerbalną, jak i reakcje złożone: werbalną i niewerbalną. Nic jednak nie wnosi w kwestii kompetencji językowej i komunikacyjnych. Akt mowy jest wolną i dowolną reakcją na świat i zdarzenia w świecie. Rozmywa się zatem granica między reakcjami typu komunikacyjnego a reakcjami na bodźce sprawcze. Tymczasem inaczej Nadawca zareaguje na łyżkę bardzo gorącej zupy w sytuacji, gdy znajduje się sam, a inaczej gdy jest w towarzystwie. To drugie dopiero wyzwala w nim reakcje typu komunikacyjnego. Wówczas bowiem raczej powstrzyma naturalną reakcję wyplucia zupy, uśmiechem usprawiedliwiając skrzywienie i wypowie jakieś niewinne kłamstwo: Smaczna, chociaż trochę może za goraca. Przepraszam.

Ch. C. Fries próbował nawet klasyfikację wypowiedzeń oprzeć na kryte- rium rodzaju reakcji na wypowiedź. Wyodrębniał on mianowicie 3 główne typy wypowiedzeń:

1. takie, po których następują reakcje słowne (tj. np. pytania);

2. takie, po których następuje reakcja w postaci jakiejś czynności (tj. np. prośby i rozkazy);

3. takie, którym towarzyszą krótkie sygnały głosowe (typu tak, uhm, aha), świadczące o uwadze słuchającego. (por. Polański 1999: 28)

Fries na pewno był prekursorski, bo chyba jako pierwszy w pewnym sensie przeczuwał, że reakcja na działanie językowe jest istotnym składnikiem komunikacyjnego zdarzenia i niejako weryfikatorem werbalnych przesłań (intencji aktu mowy czy wypowiedzi). Ale jak widać z tych prób klasyfikacyjnych, znów niestety poziomy reakcji komunikacyjnych przemieszane są z działaniami wykonawczymi (np. wykonanie prośby w reakcji na prośbę przemieszane jest ze słownymi sygnałami utrzymania więzi komunikacyjnej).

Działanie wykonawcze byłoby znakomitym sprawdzianem zarówno mocy sprawczej aktów mowy, jak i weryfikacji ich intencjonalnych założeń, ale tylko wtedy, gdyby na pytanie zawsze padała odpowiedź, a reakcją na prośbę zawsze było tylko działania pozajęzykowe. Tymczasem na wypowiedź podobnego typu (formalnie) może mieć miejsce 
różna reakcja: niejęzykowe działanie, językowe riposty albo reakcja złożona: werbalna i niewerbalna.

Jedno u Friesa wydaje się słuszne: dostrzeżenie wagi reakcji odbiorcy jako elementu znaczącego i weryfikującego stosowność użycia określonego aktu mowy i tego, że takim weryfikatorem może też być jedynie jego reakcja. Może np. na prośbę o zrobienie herbaty wyjść i ją zrobić, co wskazuje na stosowne użycie formuły proszenia. Może też zareagować oburzeniem i tylko niewerbalnie, dając wyraz temu jak niestosowna była to prośba. Ale zawsze reakcja (werbalna czy niewerbalna) będzie weryfikatorem kompetencji komunikacyjnych, a nie językowych. Kompetencji mownych, a nie systemowych.

Austin używał terminu akt mowy, jako kategorii szerszej od wypowiedzi, dlatego, że aktem mowy może być równie dobrze zdanie, jedno słowo, a nawet gest. Jak zauważa Lyons (Lyons 1989: 325), sam Austin terminu akt mowy używa rzadko, a definiując go wprawdzie uwzględnia wszystkie trzy jego płaszczyzny: lokucję, illokucję i perlokucję, tym niemniej sposoby i testy, jakie proponuje na wytyczenie granic między nimi, bywają zawodne, co w rezultacie nie pozwala nam ściśle oddzielać illokucji od perlokucji i lokucji. Jedno jest pewne, w centrum swojego zainteresowania Austin, podobnie jak jego uczeń Searle, stawia aspekt illokucyjny wypowiedzi. Zdaniem Lyonsa (325) sam termin: akt mowy jest dosyć niefortunny i potencjalnie mylący. Przede wszystkim dlatego, że nie odnosi się do samego aktu mówienia, czyli wytwarzania wypowiedzi mówionej, lecz do czegoś bardziej abstrakcyjnego, tzn. do typu lub kategorii określonego działania językowego, takiego jak zobowiązanie, kondolencje, przeprosiny itd. Z drugiej jednakowoż strony chce go rozumieć jako rzeczywiste działanie językowe, ponieważ zauważa, że aktom mowy mogą towarzyszyć, a nawet je zastępować określone zachowania niewerbalne. Np. przywołanie kogoś może być wykonane skonwencjonalizowanym ruchem ręki, zastępując wypowiedź słowną. A zatem widać, że w zamierzeniu Austina stworzona przez niego aparatura pojęciowa pozwalała, co potwierdzają współczesne badania, opisywać skonwencjonalizowane akty zachowań niewerbalnych. Ten ważny wymiar rozumienia przez Austina kategorii aktu mowy innym badaczom albo umykał, albo, tak jak w przypadku Searle'a, bywał odrzucany. To, co jednak pozostało jako najważniejszy czynnik definiujący akt mowy to jego intencjonalność.

Kognitywiści ${ }^{5}$ wprowadzają uogólnione pojęcie intencji komunikacyjnej na określenie wszelkich celów, które chcemy osiągnąć za pomocą języka, takich jak np. informowanie, proszenie, nakazywanie, namawianie, zachęcanie itd. Jako że pragmatyka zajmuje się działaniem za pomocą języka, powinna zatem określać i ustanawiać główne t y p y tych działań. 
W takim ujęciu akty mowy to $\mathrm{k}$ a t e g o r i e działań językowych. Te zaś określane są przez intencję komunikacyjną, a więc ich pragmatycznie zamierzony cel. Zatem działanie językowe utożsamiane jest z kategorią aktu mowy, co metodologicznie wydaje się niesłuszne, gdyż działanie językowe to jednak nie kategoria aktu mowy, ale konkretny akt. Można go przypisać do określonej kategorii aktu mowy i określonego typu działania językowego, ale nie zmienia to faktu, że konkretny akt nie jest ani typem ani kategorią.

Cały ten bałagan terminologiczny spowodowany jest tym, że samo pojęcie akt mowy używane jest w literaturze przedmiotu w dwóch różnych znaczeniach. Raz w znaczeniu takim, w jakim rozumie się pojęcie wypowiedź, czyli jako konkretne zachowanie mowne konkretnego nadawcy w konkretnej sytuacji, a innym razem używa się tego pojęcia dla określenia intencjonalności tej wypowiedzi, czyli tego, co ta wypowiedź miała na celu.

Stało się tak zapewne dlatego, że zbyt długo $\mathrm{w}$ pragmalingwistyce utożsamiano akt mowy z jego illokucją. Czynili to nawet sam Austin i Searle, a po nich następni, zbyt przywiązani do językowych form tworzenia określonych intencjonalności $\mathrm{w}$ znaczeniu dysponowania określonym repertuarem środków językowych. Próba poszukiwania tych środków dla wyrażenia określonych intencji (np. obiecywania) doprowadziła do tego; że sam akt mowy (już w znaczeniu illokucyjnym) mylony był i jest z kategorią tego aktu.

Tymczasem jak pokazuje analiza poglądów samych lingwistów, akt mowy rozumiany jako konkretne zachowanie mowne, właściwie niczym nie różni się od tego, co na terenie lingwistyki, uznawano za wypowiedź. Właściwie - bo głębsza penetracja tych poglądów pozwala jednak wnioskować, że badacze wyczuwali subtelne różnice między poziomem kompetencji mownej i komunikacyjnej, choć oczywiście tak tego nie nazywali. Jak najdalsi też byli od wycofania się ze stanowisk, pozwalających na wyłuskiwanie jednostek języka, a nie jednostek mowy. My jednak posuniemy się dalej: może trzeba myśleć odwrotnie? A mianowicie, że jednostki mowy to tak naprawdę jedyne jednostki systemu? I że w związku z tym ich poszukiwanie wystarczy dla zrozumienia zdolności językowych, mownych i komunikacyjnych ludzi, wyrażających się i działających za pomocą danego języka? Bo, gdy uświadomimy sobie, że na owe kompetencje składają się: zdolności kognitywne do aletycznych, epistemicznych i modalnych osądów, oraz zdolności do właściwego w danej sytuacji doboru środków językowych, i wreszcie - zdolność retoryczna osądu tego, kiedy i do kogo mówię, zrozumiemy, że na to wszystko składa się: po pierwsze zdolność wypowiadania zdań, po drugie - zdolność przekształcania ich w językowe wypowiedzi, a w końcu: kompetencja komunikacyjna do wyrażenia i przesłania określonych intencji czyli zrealizowania ich w postaci konkretnych aktów mowy. 
Czym zatem jest wypowiedź i czym ona różni się aktu mowy? Bywa, że niczym - bywa, że się różni. Wypowiedź bowiem to każde działanie w e r b a 1 n e jednego z uczestników konkretnego zdarzenia komunikacyjnego, mające na celu wyrazić określoną pragmatyczną intencję, czyli zrealizować określony akt mowy. O tym jednak, jaki to jest akt, decydują warunki pragmatyczne tej wypowiedzi, a zatem także czynniki pozajęzykowe parajęzykowe i niewerbalne, które towarzyszą temu aktowi, a właściwie konstytuują jego intencjonalność. Przykładowo, jeśli w treści propozycjonalnej wypowiedzi zawarte jest „ponowne przyjście gdzieś" w postaci wypowiedzenia Przyjdę tu znowu, to o tym, że pozorna obietnica staje się rzeczywistą pogróżką, decyduje zmiana efektów parajęzykowych (np. intonacji czy tempa wypowiedzi) i wprowadzenie elementów niewerbalnych, takich jak: potrząsanie palcem wskazującym czy marszczenie brwi. Podobnie, uznajmy, że działanie językowe typu aha lub uhmn jest pełnoprawną wypowiedzią jednego z uczestników zdarzenia komunikacyjnego, mającą za zadanie podtrzymać interaktywną więź, a osądowo to akt zgody na to, co mówi drugi uczestnik interakcji. Ale o tym, jaki jest to rodzaj zgody, znów decydują efekty parajęzykowe i niewerbalne. Aha może być szybkim potwierdzeniem lub wyrazem pośpiesznego potwierdzenia i zalążkiem nowej intencji Daj $i$ mnie coś powiedzieć., szczególnie wtedy, gdy towarzyszy mu szybkie powtórzenie wraz $\mathrm{z}$ pośpiesznym ruchem głowy i ręką uciszającą rozmówcę. Może też być wyrazem zgoła innego aktu - głębszego, prawdziwszego i bardziej refleksyjnego potwierdzenia (gdy owo aha intonowane jest wolno i na niższym poziomie głosowym). I dalej: same słowa: Koniec. Kropka! mogą być wyrazem intencjonalnego instruktażu w postaci: Daj teraz kropkę; mogą być też wyrazem zniecierpliwienia i dyrektywnym apelem do partnera o przerwanie toku rozumowania (szczególnie gdy tej wypowiedzi towarzyszy ucinający gest dłoni) itd.

Cały ten wielki wywód potrzebny był nam dla wyrażenia ostatecznych, prostych wniosków. Po pierwsze, konieczności rozróżnienia kompetencji językowych - mownych i komunikacyjnych. Po drugie, przywrócenia statycznemu pojęciu wypowiedź jego rzeczywistego, procesualnego charakteru, a w konsekwencji wprowadzenia na scenę zdarzenia komunikacyjnego odbiorcy, który poprzez swoje działania werbalne czy niewerbalne, w ostateczności może być weryfikatorem rzeczywiście przesłanych intencji, zawartych w skierowanym do niego komunikacie. Austin, myśląc o niefortunności aktu mowy, mówił o jego nadużyciu lub jego niestosowności. Zawsze jednak owo nadużycie (ang. abuse) lub niewypał (ang. misfire) kładł na karb nieszczerości lub niekompetencji samego nadawcy. Tymczasem owa niestosowność nie musi wynikać ani z niekompetencji językowej, ani $\mathrm{z}$ niewłaściwego doboru środków komunikacyjnych. Może bowiem polegać na 
niezdolności do współdziałania komunikacyjnego, czyli projektowania skutków perlokucyjnych przez rzeczywiste uwzględnienie konkretnego odbiorcy na konkretnej scenie komunikacyjnych zdarzeń. Chodzi tu o to, że z metodologicznego punktu widzenia, gdy badamy rzeczywiste skutki aktów mowy, nie możemy z góry projektować wszystkich rzeczywistych efektów ich oddziaływań. Nie możemy ich projektować szczególnie wtedy, gdy językową wypowiedź pozostawiamy poza sferą konkretnego zdarzenia komunikacyjnego, konkretnego zachowania niewerbalnego i parajęzykowego. Bo odbiorca interpretuje naszą wypowiedź na podstawie całości komunikacyjnej zdarzenia, a nie samej wypowiedzi. I dlatego on właśnie powinien być weryfikatorem rzeczywistych, projektowanych i nieprojektowanych przesłań intencjonalnych, jako że te ostatnie, niby nie projektowane, mogą być przesyłane poza świadomością owej intencjonalności. A raz przesłane, zostają mentalnie zarejestrowane i odreagowane - werbalnie lub niewerbalnie. Badanie mowy jako zjawiska komunikacyjnego musi więc uwzględniać na scenie zdarzeń rzeczywistego odbiorcę, bo dopiero jego obecność pozwala lingwiście na prawdziwe odkrycie rzeczywistych przesłań, zawartych w konkretnych działaniach językowych (wypowiedzi/ach), zanurzonych w konkretnych zachowaniach komunikacyjnych. Język bowiem nie potknął się któregoś dnia o komunikację, ale się w niej narodził.

Nowa perspektywa badawcza jest więc taka, by powrócić do badania procesu zachowań mownych i komunikacyjnych, i z tej perspektywy dopiero próbować wyznaczać jednostki mowy i ewentualnie postulować istnienie jakichś jednostek języka. $Z$ tej też racji i z powodu wszystkiego, co powyżej, pozwoliłyśmy sobie odwrócić porządek jednostek mowy i za poziom podstawowy jej pojawienia się uznać nie systemowe zdanie czy wypowiedź, a nawet nie akt mowy, ale komunikacyjne zdarzenie, w którym ta jednostka (czyli zdanie lub wypowiedź) znajduje semantyczny powód do swojego zaistnienia. Bo nawet najprostsze zdanie nie zjawia się w komunikacyjnym niebycie. Zatem, aby ułatwić wnioski wypływające z naszej rewizji tradycyjnych dla lingwistyki pojęć, pozwolimy sobie na koniec przestawić własne ich rozumienie, w postaci krótkich definicji:

ZDARZENIE KOMUNIKACYJNE - to sytuacja komunikacyjna, obejmująca przynajmniej dwa akty mowy w przestrzeni interakcyjnej między nadawcą i odbiorcą, w której dochodzi do realnej komunikacyjnej aktywności obu stron

- werbalnej, niewerbalnej, bądź mieszanej.

ZDARZENIE MOWNE - to konkretna wypowiedź, skonstruowana przez mówiącego w określonym miejscu i czasie dla określonego celu lub w reakcji na inne zdarzenie mowne. ${ }^{6}$ 
AKT MOWY -jednostka poziomu kompetencji komunikacyjnej - to każde rzeczywiste językowe lub konwencjonalne niejęzykowe (rytualne komunikacyjnie dla danej kultury) działanie mające określony i projektowany cel pragmatyczny oraz zamierzone bądź niezamierzone skutki perlokucyjne.

KATEGORIA AKTU MOWY - jednostka poziomu metajęzykowego

- to repertuar wszystkich językowych i konwencjonalnych kulturowo (prototypowych) środków i sposobów realizacji określonej intencji.

WYPOWIEDŹ - jednostka kompetencji mownej to każde rzeczywiste językowe działanie, będące wyrazem myśli, ekspresji, emocji i pragmatycznych potrzeb, wyznaczone ramami mówienia i milczenia podmiotu.

ZDANIE jednostka kompetencji językowej (systemowej) - to aletyczne orzekanie o zaistnieniu jakiegoś procesu, zdarzenia czy stanu rzeczy, semantycznie prototypowo wyrażane sądem orzekającym i zakotwiczone deiktycznie (czasowo-przestrzennie).

\section{Źródło}

Niniejszy tekst po raz pierwszy ukazał się w druku w roku 2006 w tomie Kognitywizm $i$ komunikatywizm - dwa bieguny wspótczesnego językoznawstwa, pod redakcją Władysława Chłopickiego, Język a komunikacja 9. Kraków: Tertium; 41-57.

\section{Przypisy}

\footnotetext{
${ }^{1}$ Ten sam schemat zdarzeń może jednak uzyskać różną postać realizacji zdaniowej, np.: w zależności od tego, czy istnieje potrzeba wyrażenia przez Nadawcę tzw. „transferu energii" czy nie. I tak przykładowo schemat WYDARZENIA może zostać wyrażony czasownikiem nieprzechodnim, gdy mówiący chce usunąć siebie jako sprawcę ,transferu energii" i powie: Zginął gdzieś mój zegarek; bądź przechodnim, gdy uzna swoje sprawstwo w transferze energii i powie: Zgubiłem zegarek;

${ }^{2}$ Chyba, że spreparował je badacz języka lub logik dla jakiś celów badawczych.

${ }^{3}$ Wiemy jednak, że pewne zjawiska pragmatyczne nie mogą mieć swojego trybu, tak jak nie może być „,trybu obrażania".

${ }^{4}$ Termin ,wypowiedzenie" rezerwował Klemensiewicz (1937) raczej na oznaczenie jednostki składniowej niż komunikacyjnej i kojarzył go ze zdaniem.

${ }^{5}$ Por. rozdział 7 Kognitywnych podstaw języka i językoznawstwa pod red. E. Tabakowskiej (2001), dotyczący pragmatyki mowy.

${ }^{6}$ Por. pojęcie speech event $\mathrm{u}$ Langackera (1987).
}

\section{Bibliografia}

Austin, John L. ([1961] 1993) „Jak działać słowami” [The Meaning of the Word]. [W:] 
Mówienie i poznanie. Rozprawy i wyktady filozoficzne, [Philosophical Papers, Oxford: Oxford University Press; 23-43]. [tłum. Bohdan Chwedeńczuk, Warszawa.

Jodłowski, Stanisław (1976) Podstawy składni polskiej, Warszawa: PWN

Klemensiewicz, Zenon (1937) Składnia opisowa współczesnej polszczyzny kulturalnej,

Kraków: Polska Akademia Umiejętności. Knapp, Mark L., Hall, Judith A., (2000) Komunikacja niewerbalna w interakcjach międzyludzkich. Wrocław: Astrum.

Korżyk, Krzysztof (1999) „Język i gramatyka w perspektywie 'komunikatywizmu’”.

[W:] (red.) Aleksy Awdiejew, Gramatyka komunikacyjna. Warszawa, Kraków: Wydawnictwo Naukowe PWN; 9-32.

Langacker, Ronald (1987) Foundations of Cognitive Grammar. Stanford: Stanford University Press.

Lyons, John ([1977] 1989) Semantyka. [Semantics, Cambridge: Cambridge University Press]. (tłum.) Adam Weinsberg, Warszawa: PWN.

Polański, Kazimierz (red.) (1999) Encyklopedia językoznawstwa ogólnego. Wrocław: Zakład Narodowy im. Ossolińskich.

Rudzka-Ostyn, Brygida (2000) Z rozważań nad kategoria przypadka, Kraków: Universitas.

Tabakowska, Elżbieta (red.) (2001) Kognitywne podstawy języka i językoznawstwa Kraków: Universitas.

Urbańczyk, Stanisław (red.) (1994) Encyklopedia języka polskiego. Wrocław: Zakład Narodowy im. Ossolińskich.

Yngve, Victor H. (1992) „Criteria of acceptance", Journal of Pragmatics, 17: (5-6); 549-556. 